\title{
GLACIER VOLUME ESTIMATION ON CASCADE VOLCANOES: AN ANALYSIS AND COMPARISON WITH OTHER METHODS
}

\author{
by \\ C.L. Driedger
}

(U.S. Geological Survey, Project Office-Glaciology, 1201 Pacific Avenue, Suite 450, Tacoma, WA 98402, USA)

and

P.M. Kennard

(University of Washington, Department of Geophysics, AK-50, Seattle, WA 98195, USA)

\begin{abstract}
During the 1980 eruption of Mount St. Helens, the occurrence of floods and mudflows made apparent a need to assess mudflow hazards on other Cascade volcanoes. A basic requirement for such analysis is information about the volume and distribution of snow and ice on these volcanoes.

An analysis was made of the volume-estimation methods developed by previous authors and a volumeestimation method was developed for use in the Cascade Range. A radio echo-sounder, carried in a backpack, was used to make point measurements of ice thickness on major glaciers of four Cascade volcanoes (Mount Rainier, Washington; Mount Hood and the Three Sisters, Oregon; and Mount Shasta, California). These data were used to generate ice-thickness maps and bedrock topographic maps for developing and testing volume-estimation methods. Subsequently, the methods were applied to the unmeasured glaciers on those mountains and, as a test of the geographical extent of applicability, to glaciers beyond the Cascades having measured volumes.

Two empirical relationships were required in order to predict volumes for all the glaciers. Generally, for glaciers less than $2.6 \mathrm{~km}$ in length, volume was found to be estimated best by using glacier area, raised to a power. For longer glaciers, volume was found to be estimated best by using a power law relationship, including slope and shear stress. The necessary variables can be estimated from
\end{abstract} topographic maps and aerial photographs.

\section{INTRODUCTION}

During 1980, the devastating eruption and mudflows of Mount Sț. Helens, in Washington State, made apparent the need for mudflow-hazard analysis on other Cascade volcanoes. Data on the volume and distribution of snow and ice was required for this analysis. These data were obtained by using the USGS mono-pulse radar, operating at about 5 $\mathrm{MHz}$, and carried in backpacks on these steep volcanic cones. About 200 mono-pulse radar measurements were made on 23 glaciers on Mounts Rainier, Hood, and Shasta and on the Three Sisters. Bed topography was developed on maps on scales of 1:10000 and 1:24000 on Mount Rainier; ice volumes were calculated for each glacie (Kennard, 1983).

Because of logistical constraints, not all glaciers of interest could be measured. Therefore, a scheme based on surface characteristics (slope and area) was sought, to account for the measured volumes.

Although numerous volume-estimation methods have been developed, the bedrock topography derived from measurements on the Cascade glaciers permitted establishment of equations particular to the glaciers of this region. In this paper, these methods are tested on other glaciers of known volume, in various environments in order to determine the extent of their applicability. Only a very small fraction of the world's glaciers have been sounded, so a way to estimate thickness and volume would be useful for studies of glacier flow, for volcanic hazard analysis, and for determining the spatial distribution of glacial ice.

\section{DEVELOPMENT OF THE ESTIMATION METHODS}

Glacier area is likely to correlate well with glacier volume or thickness. Others have investigated this statistical relationship, using measured glaciers for calibration, such as Brückl (1970), Paterson (1970), Müller (1976), and Macheret and Zhuravlev (1982).

Figure 1 shows the relationship between areas and volumes of measured glaciers on the Cascade volcanoes. From this graph, it can be seen that a correlation exists between area and volume, although volume can be estimated only with considerable error.

Paterson (1970), building upon the work of Nye (1952), suggested that it was possible to estimate mean glacier thickness by using glacier slope and an assumed constant shear for an infinitely-wide glacier, with laminar flow. From the relation

$$
\tau=\rho g h \sin \alpha
$$

where $\tau$ is the basal shear stress, $\rho$ is the density of ice, $g$ is the acceleration of gravity, $h$ is ice thickness, and $\alpha$ is the surface slope, the approximate relation

$$
\overline{\mathrm{h}}=\mathrm{k} / \bar{\alpha}
$$

follows, where $\bar{h}$ is the ice thickness, averaged over the area, $\bar{\alpha}$ is the average surface slope, and $k$ includes an assumed shear stress, ice density, and geometric variables. To test if the constant shear stress assumption was confirmed with the Cascade data, a basal shear stress was calculated for each glacier. This was done by subdividing each glacier into parts and calculating the interval basal shear stress $\left(\tau_{\mathrm{i}}\right)$ for each part, by an equation similar to (1):

$$
\tau_{\mathrm{i}}=\rho g \frac{\mathrm{V}_{\mathrm{i}}}{\mathrm{A}_{\mathrm{i}}} \sin \alpha_{\mathrm{i}}
$$

where $\mathrm{V}$ is volume, $\mathrm{A}$ is surface area, and the subscript, $\mathrm{i}$, indicates an interval value. The interval values are found for discrete parts of a glacier defined by arbitrary altitude limits. An interval formulation is used, because variables that strongly affect depth vary locally and these variations would be missed if the glacier were only considered as a whole. 


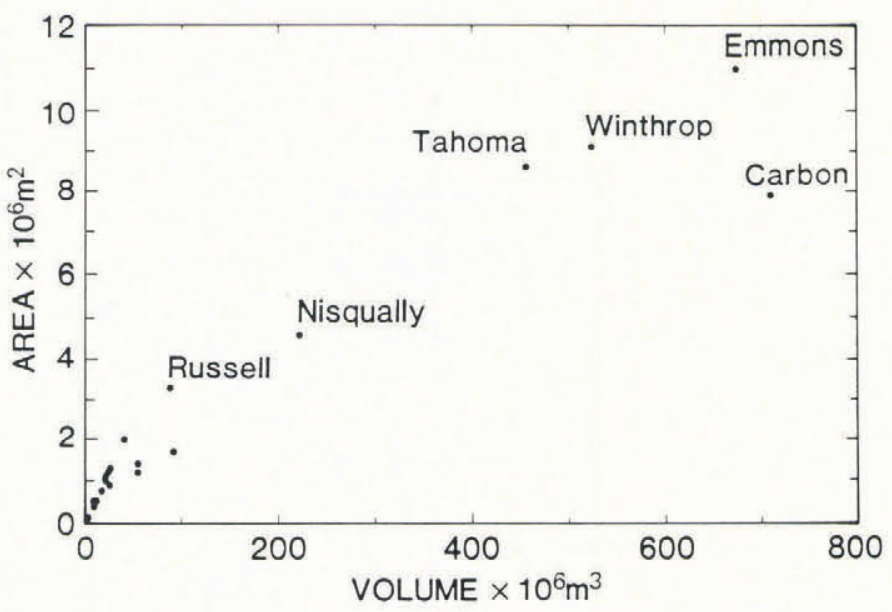

Fig.1. The volumes of measured Cascade glaciers are plotted against area. Smaller glaciers cluster near the origin while the distribution of larger glaciers suggests a power law relationship.

The average basal shear stress $(\bar{\tau})$ is found by:

$$
\bar{\tau}=\frac{\mathrm{i}^{\sum} \mathrm{W}_{\mathrm{i}} \tau_{\mathrm{i}}}{\mathrm{n}^{\sum} \mathrm{W}_{\mathrm{i}}}
$$

where $W_{i}$ is a size-weighting factor and the summations are over the entire glacier. If $\mathrm{W}_{\mathrm{i}}=1$, equation 4 calculates the mean, basal shear stress.

In Figure 2, where the mean basal shear stresses for the measured glaciers are plotted against glacier areas, the interval $\left(\tau_{i}\right)$ values were found for parts of glaciers, defined by $1000 \mathrm{ft}(300 \mathrm{~m})$ elevation intervals. As can be seen, the glaciers appear to be divided into two distinct groups: those glaciers with basal shear stresses above one bar (here termed group B glaciers), and those with a shear stress appreciably less than 1 bar (group A glaciers).

This suggests that certain glaciers (group B) reach sufficient thickness to obtain a critical shear stress. The remaining (group A) glaciers do not obtain this threshold shear stress and their value can be anything less.

For purposes of estimating ice volumes from variables derived from surface maps, we applied a basal shear stress approach to group B glaciers and an area approach to those in group $\mathbf{A}$.

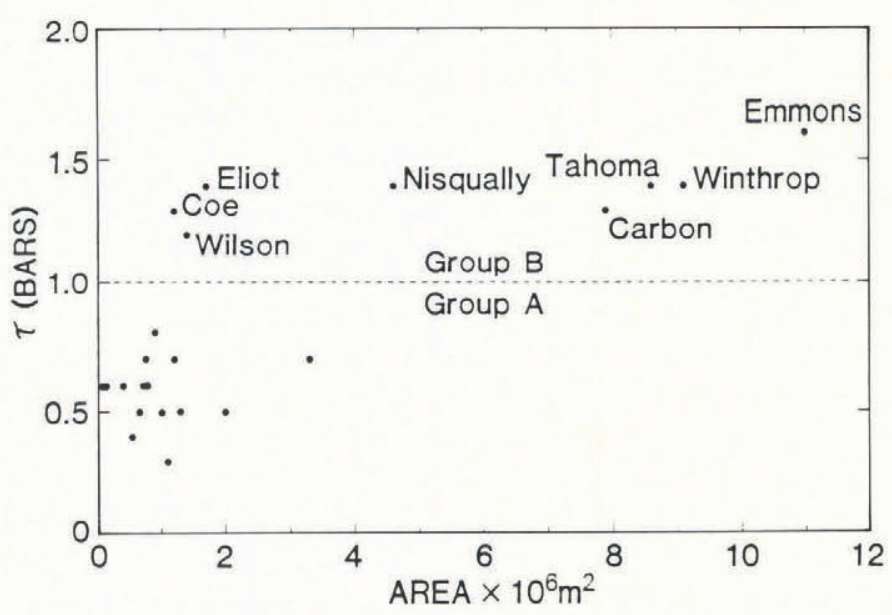

Fig.2. The graph illustrates a calculated basal shear stress versus area for glaciers in the Cascade volcano study.
Table I lists glaciers measured on the Cascade volcanoes, along with their measured volume, length, area, and calculated basal shear stress. While Figure 2 shows that the groups are not uniquely partitioned by area, from Table $I$ it is seen that those glaciers with larger areas and greater length have basal shear stresses greater than 1 bar and smaller glaciers have lower values of basal shear stress.

When glaciers with lengths exceeding $2.6 \mathrm{~km}$ are considered to be in group $\mathrm{B}$, and the others group $\mathrm{A}$, all the Cascade glaciers are assigned to their correct group.

\section{GLACIERS WITH VOLUMES THAT CORRELATED WITH BASAL SHEAR STRESS}

A volume-estimation method was sought for the group B glaciers, based on their basal shear stress $\left(\tau^{*}\right)$. The unknown volume $\left(\mathrm{V}^{*}\right)$ of a glacier, presumed to be in group $\mathrm{B}$, can be found by

$$
\mathrm{V}^{*}=\frac{\tau^{*}}{\rho \mathrm{g}} \sum_{\mathrm{i}=1}^{\mathrm{n}} \frac{\mathrm{A}_{\mathrm{i}}}{\sin \alpha_{\mathrm{i}}}
$$

once an appropriate $\tau^{*}$ can be found. The data from the measured glaciers were used to find this $\tau^{*}$ value.

When calculating a basal shear stress for a measured glacier $(\tau)$, it was found useful to apply a size-weighting factor to each altitude interval:

$$
\mathrm{W}_{\mathrm{i}}=\left(\frac{\mathrm{A}_{\mathrm{i}}}{\cos \alpha_{\mathrm{i}}}\right) \quad\left(\frac{1}{\sin \alpha_{\mathrm{i}}}\right)
$$

where $\left(\frac{\mathrm{A}_{\mathrm{i}}}{\cos \alpha_{\mathrm{i}}}\right)$ is the actual surface area and $\mathrm{A}_{\mathrm{i}}$ is the map area, the actual surface area projected onto a horizontal plane.

This result was relatively insensitive to the value used for $\mathrm{W}_{\mathrm{i}}$; similar results were obtained for $\mathrm{W}_{\mathrm{i}}=1, \mathrm{~W}_{\mathrm{i}}=\mathrm{A}_{\mathrm{i}}$, $\mathrm{W}_{\mathrm{i}}=\mathrm{V}_{\mathrm{i}}$, or $\mathrm{W}_{\mathrm{i}}$ as defined by equation (6); and for various measures of glacier size

$$
\left(\mathrm{V}, \mathrm{A}, \Sigma \frac{\mathrm{A}_{\mathrm{i}}}{\cos \alpha_{\mathrm{i}} \sin \alpha_{\mathrm{i}}}\right) \text {. }
$$

The optimum fit suggests that $\tau^{*}$ can be calculated from area and slope by the empirical relation:

$$
\tau^{*}=2.7 \times 10^{4} \sum_{i=1}^{\mathrm{n}}\left(\frac{\mathrm{A}_{\mathrm{i}}}{\cos \alpha_{\mathrm{i}}}\right)
$$

where area is in $\mathrm{m}^{2}$ and $\tau^{*}$ in Pascals $\left(1\right.$ Pascal $=10^{-5}$ bars). The best interval value of several examined, over which $A_{i}$ and $\cos \alpha_{i}$ are calculated, was found to be that defined by $1000 \mathrm{ft}(300 \mathrm{~m})$ elevation intervals.

Once $\tau^{*}$ is found for an unmeasured glacier by equation (7), volume is found by equation (5), where $\mathrm{A}_{\mathrm{i}}$ and $\sin \alpha_{i}$ are also defined by $1000 \mathrm{ft}$ intervals.

\section{AREA-CORRELATED GLACIERS}

For the smaller (group A) glaciers, a regression analysis was done on the area-volume relationship. The final relation that minimizes the individual glacier percentage and magnitude differences is

$$
V^{*}=3.93 A^{1.124}
$$

where $A$ is the total area in $\mathrm{m}^{2}$ and the estimated volume $\mathrm{V}^{*}$ is in $\mathrm{m}^{3}$ (Kennard, 1983), and is shown in Figure 3. 
TABLE I RADAR MEASURED GLACIERS ON THE CASCADE VOLCANOES, INDICATING LOCATION AND ASSOCIATED BASAL SHEAR STRESS, AREA, MEASURED VOLUME, AND GLACIER LENGTH. THE LOCATIONS ARE INDICATED BY (R) MOUNT RAINIER, $46^{\circ} 50^{\prime} \mathrm{N}$, $121^{\circ} 45^{\prime} \mathrm{W}$; (H) MOUNT HOOD, $45^{\circ} 20^{\prime} \mathrm{N}, 121^{\circ} 30^{\prime} \mathrm{W}$; (T) THREE SISTERS, $44^{\circ} 10^{\prime} \mathrm{N}, 121^{\circ} 25^{\prime} \mathrm{W}$.

\begin{tabular}{|c|c|c|c|c|c|c|}
\hline $\begin{array}{l}\text { Measured } \\
\text { glacier }\end{array}$ & Location & Group & $\begin{array}{c}\text { Basal shear } \\
\text { stress, in bars }\end{array}$ & $\begin{array}{r}\text { Area } \\
k m^{2}\end{array}$ & $\begin{array}{l}\text { Volume } \\
\times 106 m^{3}\end{array}$ & $\begin{array}{c}\text { Map length } \\
\text { of glacier } \\
\mathrm{km}\end{array}$ \\
\hline $\begin{array}{l}\text { Emmons } \\
\text { Winthrop } \\
\text { Tahoma } \\
\text { Carbon } \\
\text { Nisqually } \\
\text { Russell } \\
\text { Newton Clark }\end{array}$ & $\begin{array}{l}R \\
R \\
R \\
R \\
R \\
R \\
H\end{array}$ & $\begin{array}{l}B \\
B \\
B \\
B \\
B \\
A \\
A\end{array}$ & $\begin{array}{l}1.6 \\
1.4 \\
1.4 \\
1.3 \\
1.4 \\
0.7 \\
0.5\end{array}$ & $\begin{array}{r}11.0 \\
9.1 \\
8.6 \\
7.9 \\
4.6 \\
3.3 \\
2.0\end{array}$ & $\begin{array}{l}67 . \\
52 . \\
46 . \\
71 . \\
22 . \\
88 . \\
40 .\end{array}$ & $\begin{array}{l}7.2 \\
8.1 \\
7.4 \\
9.7 \\
6.6 \\
2.4 \\
2.0\end{array}$ \\
\hline $\begin{array}{l}\text { Eliot } \\
\text { Wilson } \\
\text { Coe }\end{array}$ & $\begin{array}{l}\mathrm{H} \\
\mathrm{R} \\
\mathrm{H}\end{array}$ & $\begin{array}{l}B \\
B \\
B\end{array}$ & $\begin{array}{l}1.4 \\
1.2 \\
1.3\end{array}$ & $\begin{array}{l}1.7 \\
1.4 \\
1.2\end{array}$ & $\begin{array}{l}91 . \\
54 . \\
54 .\end{array}$ & $\begin{array}{l}4.0 \\
2.6 \\
3.3\end{array}$ \\
\hline $\begin{array}{l}\text { Sandy } \\
\text { Collier } \\
\text { Prouty }\end{array}$ & $\begin{array}{l}\mathrm{H} \\
\mathrm{T} \\
\mathrm{T}\end{array}$ & $\begin{array}{l}A \\
A \\
A\end{array}$ & $\begin{array}{l}0.7 \\
0.3 \\
0.5\end{array}$ & $\begin{array}{l}1.2 \\
1.1 \\
1.0\end{array}$ & $\begin{array}{l}23 . \\
20 . \\
20 .\end{array}$ & $\begin{array}{l}1.9 \\
2.1 \\
1.6\end{array}$ \\
\hline $\begin{array}{l}\text { Ladd } \\
\text { ZigZag } \\
\text { Reid } \\
\text { Hayden } \\
\text { Diller }\end{array}$ & $\begin{array}{l}H \\
H \\
H \\
T \\
T\end{array}$ & $\begin{array}{l}A \\
A \\
A \\
A \\
A\end{array}$ & $\begin{array}{l}0.8 \\
0.6 \\
0.7 \\
0.6 \\
0.5\end{array}$ & $\begin{array}{l}.9 \\
.78 \\
.75 \\
.72 \\
.66\end{array}$ & $\begin{array}{l}25 . \\
17 . \\
17 . \\
17 . \\
14 .\end{array}$ & $\begin{array}{l}2.0 \\
2.4 \\
1.9 \\
1.3 \\
1.2\end{array}$ \\
\hline $\begin{array}{l}\text { White River } \\
\text { Lost Creek } \\
\text { Langille } \\
\text { Palmer } \\
\text { Coalman }\end{array}$ & $\begin{array}{l}H \\
T \\
H \\
H \\
H\end{array}$ & $\begin{array}{l}A \\
A \\
A \\
A \\
A\end{array}$ & $\begin{array}{l}0.4 \\
0.4 \\
0.6 \\
0.6 \\
0.6\end{array}$ & $\begin{array}{l}.54 \\
.54 \\
.4 \\
.13 \\
.08\end{array}$ & $\begin{array}{c}8.5 \\
11 . \\
8.5 \\
2.0 \\
1.1\end{array}$ & $\begin{array}{r}1.9 \\
1.4 \\
1.5 \\
.4 \\
.5\end{array}$ \\
\hline
\end{tabular}
* (A) indicates that a volume-to-area relation was used to estimate volume; (B) indicates a relation
with basal shear stress

\section{APPLICATION OF THE METHOD TO OTHER GLACIERS}

In order to test the geographical applicability of these estimation methods, they were applied to some glaciers with well-measured basal topography. The glaciers' locations and dimensions are listed in Table II. The estimation methods gave satisfactory results when the glaciers were assigned to the correct group, yielding a standard deviation error for volume of less than 8 per cent.

However, three of the nine glaciers (Isfalls, Whitney, Grinnell) were assigned to the wrong group, when the length criterion developed for the measured glaciers in the Cascades was used. An incorrect assignment of an unmeasured glacier introduces significant error, discussed later.

The estimation methods were applied to the whole glacier, in all but two cases. The Athabasca Glacier, of British Columbia, is an outlet glacier of the much larger Columbia Icefield, where only the ablation area was measured and later estimated. The Dinwoody Glacier, in the Wind River Range of Wyoming (USA), is composed of a compound cirque accumulation area. The volume was established only in the two southern cirques, through the terminus, because radar measurements were completed in this region only.

\section{COMPARISON WITH OTHER METHODS}

A comparison was made of measured and estimated volumes, as calculated with the methods of Driedger and Kennard, 1984; Post and others, 1971; Müller, 1976; and Macheret and Zhuravlev, 1982.

Paterson (1970) and others built upon the work of Nye (1952) and others to make theoretical calculations of $\bar{h}$. But it was not until there was an accumulation of published, sub-glacial, topographic data, that volume estimation methods could be developed.

One of the earlier estimation procedures was suggested in Post and others (1971), where glaciers were assigned volumes according to five size classes. A mean thickness was established for each area category $(20 \mathrm{~m}$ for areas between 0 and $0.5 \mathrm{~km}^{2} ; 40 \mathrm{~m}$ for areas between 0.5 and $1 \mathrm{~km}^{2} ; 65 \mathrm{~m}$ for areas between 1 and $2 \mathrm{~km}^{2} ; 90 \mathrm{~m}$ for areas betwen 2 and $5 \mathrm{~km}^{2}$; and $120 \mathrm{~m}$ for areas between 5

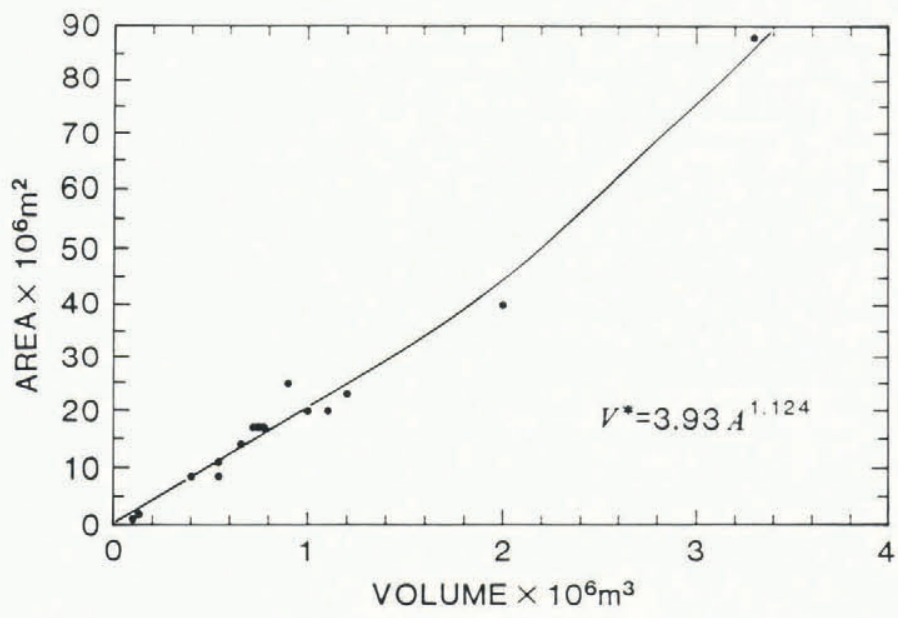

Fig.3. The graph illustrates the power curve $\mathrm{V}=$ $3.93 \mathrm{~A}^{1.124}$. derived when area is plotted against measured volume for smaller (group A) glaciers in the Cascades. 
TABLE II OTHER GLACIERS INCLUDED IN TEST OF THE METHODS' GEOGRAPHICAL APPLICABILITY. GROUP DESIGNATION REFERS TO THE USE OF AN AREA (A) OR BASAL SHEAR STRESS (B) RELATION TO VOLUME. THE ESTIMATED VOLUMES WERE OBTAINED, USING THE METHODS DESCRIBED IN THIS PAPER

\begin{tabular}{|c|c|c|c|c|c|c|c|c|c|c|}
\hline Glacier & Location & Country & Lat., Long. & $\begin{array}{l}\text { Area } \\
\left(\mathrm{km}^{2}\right)\end{array}$ & $\begin{array}{l}\text { Length } \\
(\mathrm{km})\end{array}$ & $\begin{array}{c}\bar{h} \\
(\mathrm{~m})\end{array}$ & $\begin{array}{r}\text { Volum } \\
\times 10^{6} \mathrm{~m} \\
\text { meas. }\end{array}$ & $\begin{array}{l}\text { me } \\
m^{3} \\
\text { est. }\end{array}$ & Group & Reference \\
\hline Rabots & $\begin{array}{l}\text { Kebnekaise } \\
\text { Massif }\end{array}$ & Sweden & $67^{\circ} 55^{\prime} \mathrm{N} ; 11^{\circ} 30^{\prime} \mathrm{E}$ & 4.1 & 3.6 & 84 & 346 & 372 & B & $\begin{array}{l}\text { Björnsson } \\
1981\end{array}$ \\
\hline Athabasca & $\begin{array}{l}\text { Rocky } \\
\text { Mountains }\end{array}$ & $\begin{array}{l}\text { British Col., } \\
\text { Canada }\end{array}$ & $51^{\circ} 40^{\prime} \mathrm{N} ; 116^{\circ} 50^{\prime} \mathrm{W}$ & 3.8 & 3.6 & 150 & 574 & 600 & B & $\begin{array}{l}\text { Tr embley } \\
\text { written com. } \\
1985\end{array}$ \\
\hline Stor & $\begin{array}{l}\text { Kebnekaise } \\
\text { Massif }\end{array}$ & Sweden & $67^{\circ} 64^{\prime} \mathrm{N} ; 18^{\circ} 36^{\prime} \mathrm{E}$ & 3.1 & 3.5 & 99 & 306 & 303 & B & $\begin{array}{l}\text { Björnsson } \\
1981\end{array}$ \\
\hline S. Cascade & $\begin{array}{l}\text { North Cascades } \\
\text { Range }\end{array}$ & $\begin{array}{l}\text { Washington, } \\
\text { USA }\end{array}$ & $48^{\circ} 122^{\prime} \mathrm{N} ; 121^{\circ} 3^{\prime} \mathrm{W}$ & 2.0 & 3.3 & 99 & 196 & 198 & B & Hodge, 1979 \\
\hline Dinwoody* & $\begin{array}{l}\text { Wind River } \\
\text { Range }\end{array}$ & $\begin{array}{l}\text { Wyoming, } \\
\text { USA }\end{array}$ & $43^{\circ} 10^{\prime} \mathrm{N} ; 109^{\circ} 40^{\prime} \mathrm{W}$ & 1.5 & 2.6 & 55 & 80 & 100 & B & \\
\hline Isfalls & $\begin{array}{l}\text { Kebnekaise } \\
\text { Massif }\end{array}$ & Sweden & $67^{\circ} 55^{\prime} \mathrm{N} ; 18^{\circ} 35^{\prime} \mathrm{E}$ & 1.3 & 2.0 & 72 & 92 & 82 & B & $\begin{array}{l}\text { Björnsson } \\
1981\end{array}$ \\
\hline Whitney & Mount Shasta & $\begin{array}{l}\text { California, } \\
\text { USA }\end{array}$ & $41^{\circ} 30^{\prime} \mathrm{N} ; 121^{\circ} 50^{\prime} \mathrm{W}$ & 1.3 & 2.8 & 20 & 26 & 29 & A & $\begin{array}{ll}\text { Driedger and } \\
\text { Kennard, } 1984\end{array}$ \\
\hline Grinnell & $\begin{array}{l}\text { Rocky } \\
\text { Mountains }\end{array}$ & $\begin{array}{l}\text { Montana, } \\
\text { USA }\end{array}$ & $48^{\circ} 50^{\prime} \mathrm{N} ; 113^{\circ} 50^{\prime} \mathrm{W}$ & 1.0 & 1.0 & 64 & 62 & 59 & B & \\
\hline Maclure & $\begin{array}{l}\text { Sierra Nevada } \\
\text { Mountains }\end{array}$ & $\begin{array}{l}\text { California, } \\
\text { USA }\end{array}$ & $37^{\circ} 40^{\prime} \mathrm{N} ; 119^{\circ} 10^{\prime} \mathrm{W}$ & .2 & .8 & 17 & 4 & 4.2 & A & \\
\hline
\end{tabular}

* Only the two southern-most cirques and the terminus region of the glacier were estimated in this study because they are the only portions measured by ice radar.

and $10 \mathrm{~km}^{2}$ ). These relations were based upon gravity and drilling measurements on Pacific North-west glaciers, as well as measurements of some small Russian and Canadian glaciers, as described by Ommanney, 1969.

Müller (1976) developed a scheme whereby glaciers are divided into size categories and a mean thickness is assumed for each category, according to

$$
\mathrm{A}<0.5 \mathrm{~km}^{2}, \overline{\mathrm{h}}=5 \mathrm{~m} \text {; }
$$

$0.5<\mathrm{A} \leq 23 \mathrm{~km}^{2}, \overline{\mathrm{h}}=5.2+15.4 \mathrm{~A}^{\frac{1}{2}}$

and, for $A>23 \mathrm{~km}^{2}$ (where $A$ is in $\mathrm{km}^{2}$ and $\overline{\mathrm{h}}$ is in meters), volume determination is done on an individual basis. The relations were developed using area and mean thickness values for 16 mountain and valley glaciers in the Alps, as derived from the methods of Brückl (1970), whose method alone can only be applied to glaciers for which some thickness information is known beforehand. Similar volume estimates were made by Østrem et al (1973) in the determination of glacier volumes in Scandinavia.

Macheret and Zhuravlev (1982) made parabolic approximations of radar-sounded cross-sections on 59 glaciers of Svalbard. They determined that volume was related to area according to the relation:

$$
\mathrm{V}=11.4 \mathrm{~A}^{1.120}
$$

where $\mathrm{A}$ is in $\mathrm{m}^{2}$, and $\mathrm{V}$ is in $\mathrm{m}^{3}$. The exponent above is the same, to three significant figures, as in the Cascades estimation method for group A glaciers (equation 8); the coefficient, however, is approximately three times that of the Cascades method.
Usable maps of Svalbard sub-glacial topography were not readily available. Also, additional study by Dowdeswell and others (1984) shows that more recent radar interpretations may yield greater volumes than currently published.

Therefore, no other methods were tested on Svalbard glaciers, although their method was applied to glaciers elsewhere.

Table III illustrates the relationship of the measured volumes to those found with three estimation methods.

\section{CONCLUSIONS}

Based on application to the original measured Cascade glaciers, the root mean square for the individual glacier estimated volume percentage errors was $13 \%$ for group A and B glaciers together. With an estimated uncertainty of \pm 20 per cent, for the Cascade measured volumes (Kennard, 1983), the error in determining the unknown volume of an unknown glacier is estimated to be $25 \%$.

This does not include the potential error associated with incorrectly designating the glacier group, prior to estimating volume. For larger glaciers, the volume difference, caused by improper designation, can exceed 100 per cent.

The empirical criterion for assignment to Group A or B was shown to be reliable only in the Cascades. There is an interval of uncertainty for glaciers of lengths from about 2.8 to $1.0 \mathrm{~km}$. Until a more fundamental, differentiation method is found, it is suggested that photographs of glaciers in this intermediate zone be compared with known glaciers of both groups. Relative size and shape and evidence of relative thickness, as expressed by surface morphology, should help in more positive identification. 


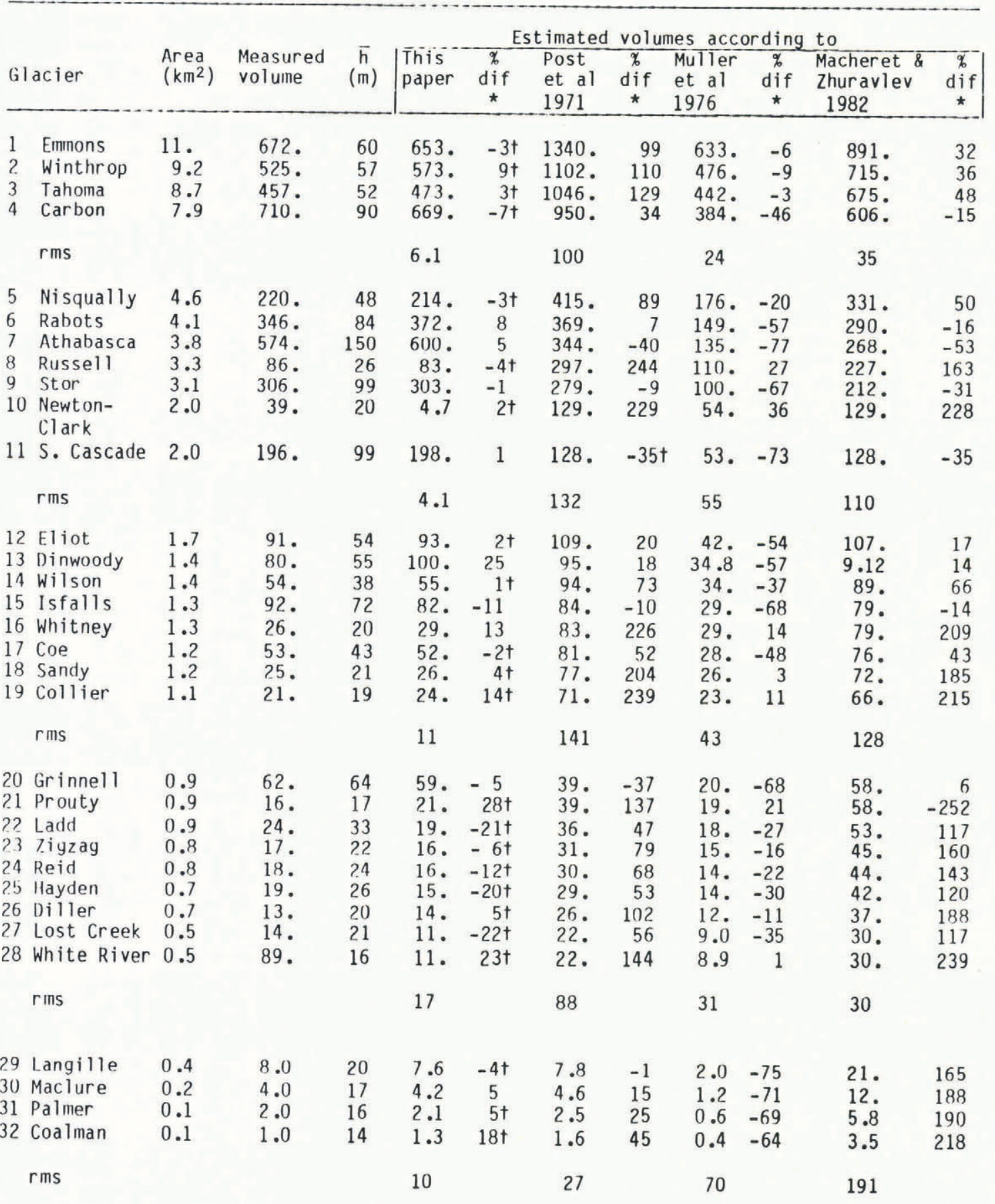

\footnotetext{
* percentage difference from measured volume.

+ signifies glaciers from which methods were developed.
}

\section{REFERENCES}

Björnsson H 1981 Radio-echo sounding maps of Storglaciären, Isfallsglaciären, and Rabots glaciär, northern Sweden. Geografiska Annaler 63A(3-4): 225-231

Brückl E 1970 Eine Methode zur Volumbestimmung von Gletschern auf Grund der Plastizitätstheorie. Archiv für Meteorologie, Geophysik und Bioklimatologie Ser A 19(3): 317-328

Brzozowski J, Hooke R L 1981 Seasonal variations in surface velocity of the lower part of Storglaciären, Kebnekaise, Sweden. Geografiska Annaler 63A(3-4): 233-240
Dowdeswell J A, Drewry D J, Liestøl O, Orheim O 1984 Radio echo-sounding of Spitsbergen glaciers: problems in the interpretation of layer and bottom returns. Journal of Glaciology 30(104): 16-21

Driedger C L, Kennard P M 1984 Ice volumes on the Cascade volcanoes: Mount Rainier, Mount Hood, Three Sisters, and Mount Shasta. US Geological Survey. Open File Report 84-581

Kennard P M Unpublished Volumes of glaciers on Cascade volcanoes. (Master's thesis, University of Washington, 1983) 
Macheret Yu Ya, Zhuravlev A B 1982 Radio echo-sounding of Svalbard glaciers. Journal of Glaciology 28(99): 295-314

Müller F, Caflisch T, Müller G 1976 Firn und Eis der Schweizer Alpen. Gletscherinventar. Zürich, Eidgenössische Technische Hochschule. Geographisches Institut (Publikation 57)

Nye J F 1952 The mechanics of glacier flow. Journal of Glaciology 2(12): 82-93

Ommanney C S L 1969 A study in glacier inventory. The ice masses of Axel Heiberg Island, Canadian Arctic Archipelago. McGill University. Axel Heiberg Island Research Reports. Glaciology 3

Østrem G, Haakensen N, Melander O 1973 Atlas over breer i Nord-Skandinavia. Norges Vassdrags- og Elektrisitetsvesen. Hydrologisk Avdeling. Meddelelser 22

Paterson W S B [1971] The application of ice physics to glacier studies. In Demers J (ed) Glaciers. Proceedings of the Workshop Seminar...September 24 and 25, 1970. Ottawa, Secretariat, Canadian National Committee for the International Hydrological Decade: 43-46

Post A, Richardson D, Tangborn W, Rosselot F 1971 Inventory of glaciers in the North Cascades, Washington. US Geological Survey. Professional Paper 705-A

Schytt V 1959 The glaciers of the Kebnekajse-massif. Geografiska Annaler 41(4): 213-227 